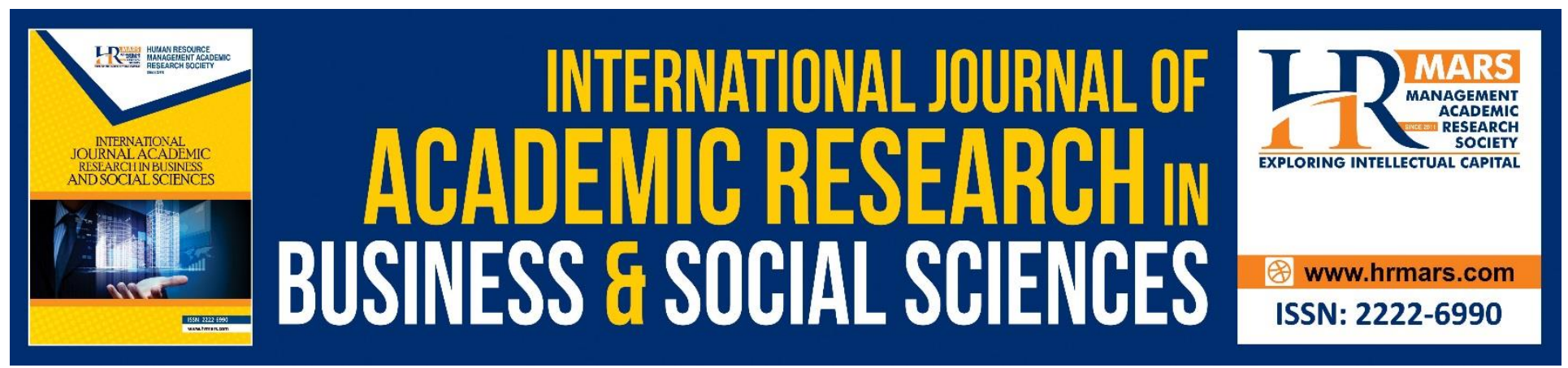

\title{
Linguistic Disorders for Basic Stage Students from Female Teachers Point of View in The Governorate of Irbid
}

\author{
Alaa Majed Alkhlouf, Mustafa bin Che Omar, Mustafa Kazakzeh
}

To Link this Article: http://dx.doi.org/10.6007/IJARBSS/v10-i8/7525

DOI:10.6007/IJARBSS/v10-i8/7525

Received: 18 May 2020, Revised: 20 June 2020, Accepted: 24 July 2020

Published Online: 21 August 2020

In-Text Citation: (Alkhlouf et al., 2020)

To Cite this Article: Alkhlouf, A. M., Omar, M. bin C., \& Kazakzeh, M. (2020). Linguistic Disorders for Basic Stage Students from Female Teachers Point of View in The Governorate of Irbid. International Journal of Academic Research in Business and Social Sciences, 10(8), 202-215.

Copyright: (C) 2020 The Author(s)

Published by Human Resource Management Academic Research Society (www.hrmars.com)

This article is published under the Creative Commons Attribution (CC BY 4.0) license. Anyone may reproduce, distribute, translate and create derivative works of this article (for both commercial and non-commercial purposes), subject to full attribution to the original publication and authors. The full terms of this license may be seen

at: http://creativecommons.org/licences/by/4.0/legalcode

Vol. 10, No. 8, 2020, Pg. 202 - 215

http://hrmars.com/index.php/pages/detail/IJARBSS

JOURNAL HOMEPAGE

Full Terms \& Conditions of access and use can be found at http://hrmars.com/index.php/pages/detail/publication-ethics 


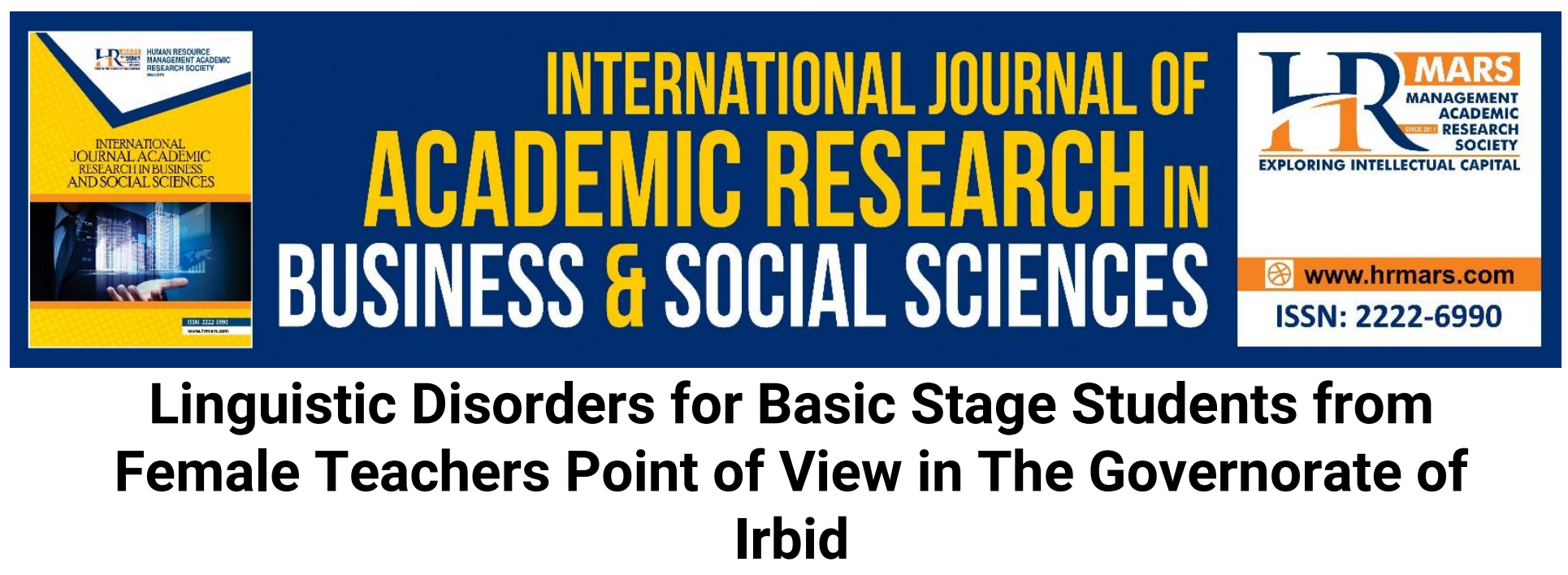

\author{
Alaa Majed Alkhlouf, Mustafa bin Che Omar, Mustafa Kazakzeh \\ Faculty of Islamic Contemporary studies, UniSZA, Terengganu, Malaysia. \\ Email: alaa.unisza@gmail.com,mustafa@unisza.edu.my,mustafa.unisza@gmail.com
}

\begin{abstract}
Some students in the basic stage suffer from language disorders as language disorders become one of the most common learning difficulties that affect the academic level of many basic stage students. Hence, this study aims to identify the language disorders experienced by basic stage students from the teachers' point of view. This study depends on the quantitative approach to prepare the theoretical framework, build the study's appropriate tool to apply, analyze and interpret the results. To achieve the goals of the study, a questionnaire was developed for data collection, and its sincerity and consistency was confirmed. The questionnaire consists of 25 items; the study sample consists of 148 basic stage female teachers from the city of Irbid, Al Wasatia District. To answer the study questions, the arithmetic mean and standard deviations for linguistic disorders were calculated, and the results of the study showed that respondents' perceptions of linguistic disorders items came with an average degree. While the results showed that there were no statistically significant differences among students in the level of language disturbances from teachers' point of view due to variables of age, educational qualification and grade of study, the study, however, showed that there are statistically significant differences due to years of experience variable.
\end{abstract}

Keywords: Language, Language Disorders, Basic Stage.

\title{
Introduction
}

Language acquisition is an important and fundamental issue during the first six years of a child's life. The child's ability to create a linguistic crop, and to use the language to communicate clearly and soundly is the cornerstone of the learning process. Therefore, this process is considered the main pillar for the success of the educational process (Celia and Nymph, 2016).

Scholars were interested in searching for all kinds of linguistic disorders that students may encounter during the academic stages, searching for their psychologically, physiologically or socially causes and manifestations. The scholars went further to search for how to treat them, especially when these disturbances negatively affect communication, child's life, school stages and the community (Ulu, 2015). 
INTERNATIONAL JOURNAL OF ACADEMIC RESEARCH IN BUSINESS AND SOCIAL SCIENCES Vol. 10, No. 8, 2020, E-ISSN: 2222-6990 @ 2020 HRMARS

\section{The Problem of the Study}

Language disorders are one of the most important topics in the field of special education as educators have indicated that these disorders may be related to form of language disorder (grammatical, morphological and phonological system), its content (semantic system) and its use in the functional communication process. The disorder may possibly appear in one or more of these three aspects of language which compels researchers to study this problem, and to find treatment strategies, educational and pedagogical programs that assist linguistically disturbed persons (Celia and Houria, 2016).

Linguistic disorder is considered as one of the main problems experienced by children with academic learning difficulties, which include stuttering and exchanging disorders. Stuttering main manifestations appear in the repetition of sounds and syllables, or pauses during a speech, or hesitations and confusion accompanied by secondary manifestations such as anxiety and frustration feelings, avoidance behaviours, reluctance and flight, and all the various physical movements that are observed by the listener and impede the flow of speech in its natural form in affecting the flexibility and smoothness of speeches. This disorder manifests itself in some situations that are accompanied by high levels of tension, especially the troubled social situations (Hallahan, Kuffman \& Pullen, 2012).

Besides, the substitution faults of children with learning difficulties lead to behavioural, social and psychological problems. Children who mispronounce words feel embarrassed and confused in front of the group, and therefore they hate being asked to speak in front of others because they fear others ridicule them, and often this embarrassment may result in a rejection feeling from others, introversion and withdrawal from social attitudes, frustration and a sense of failure, inferiority or guilt feeling, or aggression towards oneself or others (Al-Badur, 2013).

This study observes that there is potential for future tension if no study verifies whether these basic students are specifically influenced by speech disorders or language disorders. The paper attempts to focus on finding the root-causes of linguistic disorders between organic disturbances and functional disorders. The paper differs from previous studies because speech sounds and voice quality are determined in the students' language disorders. Of the studies that comprehensively investigated linguistic disorder in Irbid, few have delved into establishing where the problem emanates from between articulation and phonological disorder. The difficult speech sounds of the students were not distinguished from the easy ones.

Despite that the basic stage students were characterized as having a linguistic impairment, it is important to explore the role of mental retardation, autism and cerebral palsy in linguistic disorders. A common limitation among literature is the lack of a comprehensive overview of the influence of first language development in these disorder challenges. The problem of these students was also not viewed from the perspective of inherited disorders. Hence, there is a need to provide detail account on the emergence of linguistic disorders among these basic students.

\section{Questions of the Study}

1- What are the basic level students' language disorders from female teachers' viewpoint in public schools in the Al-Wasatia district, in the governorate of Irbid? 
INTERNATIONAL JOURNAL OF ACADEMIC RESEARCH IN BUSINESS AND SOCIAL SCIENCES Vol. 10, No. 8, 2020, E-ISSN: 2222-6990 @ 2020 HRMARS

2- Are there statistically significant differences in linguistic disturbances among the basic level students from female teachers' point of view due to the demographic variables such as (age, educational qualification, years of experience and teacher's grade of study?

\section{The Hypothesis of the Study}

There are no statistically significant differences at the level of significance $(\alpha \leq 0.05)$ in the linguistic disorder of basic level students from female teachers' point of view due to demographic variables such as (age, educational qualification, years of experience teacher's grade of study).

\section{Objectives of the Study}

1- Examining language disorders among basic level students from female teachers' viewpoint in Irbid Governorate.

2- Detecting of statistically significant differences caused by demographic variables such as (age, educational qualification, years of experience, and teacher's grade of study) in linguistic disorder from basic level female teachers' viewpoint.

\section{The Approach of the Study}

The research relied on the quantitative descriptive approach as it is defined as phenomena study that exists in reality. It is an attempt to reach accurate and detailed knowledge of elements of an existing problem or phenomenon to reach a clearer and detailed understanding of its future policies and procedures. This curriculum aims to provide data and facts about the problem (the subject of the research), its interpretation and to determine its implications and development over time (Jalghoum, 2007).

\section{Study Community}

The study population consists of the basic level female teachers working in government schools affiliated to the Ministry of Education in Irbid (Al-Wasatiya Brigade), where permission was obtained from the Directorate of Education for the Irbid Governorate (Al-Wasatiya District) by distributing a questionnaire to the teachers in more than one school in the affiliated government schools. The number of female teachers affiliated with the Ministry reached (240). Accordingly, the study community consists of female teachers working in these government schools affiliated to it, and the number of female teachers affiliated to the Ministry has reached (240) female teachers.

\section{Sample of the Study}

The current study sample consists of (Morgan's) schedule of (148) female teachers randomly chosen for the basic level of Ministry of Education in Al-Wasatia District for the second semester 2017/2018.

\section{The Concept of Language}

Language is a means of expressing oneself and understanding others. It is a linguistic structure, cognitive and emotional growth, through which people get communicated and acquainted (Fayoumi, 2017).

Language is one of the most important factors in communicating with others, because it contains skills such as speaking, listening, reading and writing, and each of these skills represents one of the windows of knowledge and the transmission of life experiences throughout the ages. Therefore, 
INTERNATIONAL JOURNAL OF ACADEMIC RESEARCH IN BUSINESS AND SOCIAL SCIENCES Vol. 10, No. 8, 2020, E-ISSN: 2222-6990 @ 2020 HRMARS

language is one of the most important characteristics that God Almighty singled out for humans to be unique in that of all creatures. However, it is only a person that can use and employ the language, whether spoken or written, to achieve contact and communication with people of his race, regardless of their environment (Nubian, 2011).

Al-Faramawy believes that language is a set of recognized symbols, whether these symbols are phonemic or non-phoneme, such as signs, gestures, and facial expressions, as individuals use them to communicate and interact with each other (Al-Faramawi, 2009).

\section{Language Disorders}

Language disorders constitute a broad sector in the field of learning difficulties. In its essence, it is due to a functional neurological dysfunction in the central nervous system where an individual's ability to understand and use the language is affected by learning disabilities. If language disorder is closely looked, it is discovered that all educational tasks, that include the use of language such as listening, thinking, speaking, reading, writing, and numeracy, can only be learned through language, and this is under the view of Faramawi (2009).

Didouh (2016) believed that language disturbance is any difficulty in producing or receiving linguistic units regardless of the environment that ranges in this, whether in the total absence from speech to the different presence in the production of grammar and useful language, but with little level and few vocabularies.

Mahmoud (2007) indicated that linguistic disorders are difficulties in the receptive language, difficulties in receiving and understanding the language, difficulties in expressive language and difficulty in an individual's ability to verbally express himself.

\section{The Basic Stage}

It starts from 6 years to 16 years old, and starts from the first grade and ends in the tenth grade. It is a mandatory stage in which students are established, especially in Arabic, mathematics and English (http://www.moe.gov.jo/ar/node/15782).

\section{Theoretical Framework and Previous Studies}

The scholars differed regarding the naming of linguistic problems that some children might suffer from. In the past, Al-Jahiz called it flaws in speech, and recently, it was called by many different names, including linguistic deficiency, linguistic deficit, linguistic deficiency or linguistic disability. Didouh (2016) believed that these people have a human, psychological, and social value, and they have their human rights, so it is best to call them children with language disorders to avoid their description of disability (Didouh, 2016).

Certain factors including genetic susceptibility, cognitive abilities, brain damage, Down syndrome, attention disorder, hearing and vision impairment may constitute a linguistic disorder. American Psychiatric Association (2013) opined that language disorder should not be limited to just a particular skill but it needs to influence several skills such as speaking, writing and sign language. Linguistic disorders could not be diagnosed except if the communicative, social and vocational performances of these students are far below expectations (APA, 2013). Tomblin, Records and Zhang (1997) used performances in vocabulary, syntax, discourse processes, language comprehension, language production, grammatical and narrative skills to determine children language disorders. 
A detailed case history, behavioural reactions, medical status, educational performance and interviews with the patient and all other members of the patient's family needs to be emphasized in the findings of the causes of linguistic disorders. Every aspect of the patient's life affected by the language requires the attention of several professionals in different fields (World Health Organization, 2010). These multi-professional attentions imply that healthcare and educational services would be guaranteed.

Woods et al., (2014) argued that the probability of identifying children with linguistic disorder is relatively low because it may not be discovered before 24 months of age. Newborg (2005) used the Battelle Developmental Inventory to gather developmental age scores for personal-social skills, adaptive characters, communication skills and cognitive abilities. Paul (2012) suggested that a particular standardized test is required of a linguistic disorder patient to ascertain the efficiency of the individual's communication skills. Therefore, the present study aims to be a valuable source for students having linguistic disorder issues at Irbid.

\section{Classification of Language Disorders}

Language disorders are also categorized into several types as indicated by (Arar and Al-Hashemi 2016), including:

1 - Language Delay: It is indicated in it for the child who uses a very simple language in the stages in which the language usually grows, which leads to the slow and delayed language acquisition. In this case, the child's first word does not appear at the normal age of its appearance, which leads to a weak linguistic crop of the child and thus affects reading and writing in the future.

2 - Language Stroke (Avazia): It is the loss of the ability to speak at the appropriate time, knowing that individual knows what he wants to say and that this is caused by a disease in the centres of the brain.

3 - Writing Difficulty: In this case, the child cannot correctly write the material that he is required to write, and it is expected to be written by those of his age.

4- Sentence Synthesizing Difficulty: It is the inability to synthesize sentence words, in terms of language grammar to give the correct meaning, since in this case, the child has difficulty in putting the right word in the right place.

5- Reading Difficulties: The reading process is not a mechanical process that is based on merely recognizing letters and words and pronouncing them, but rather it is a complex process that represents all the processes that a person performs in learning. It requires (understanding, linking, and deducing), and in the event of a child reading difficulty. In this case, the child cannot correctly read the written material and the child is required to read it.

6- Remembering and Expressing Difficulty: In this case, it is difficult for the child to remember the appropriate word in the right place and then express it. In this case, the child resorted to placing any word instead of that word, which leads to the lack of coherence and consistency in what the child says.

\section{Causes of Language Disorders}

As indicated by Al-Dabbas (2013), Ulu, Fatima (2015), Celia and Huriya (2017), linguistic disorders have several reasons, including neurological, physiological, environmental, or psychological: 
INTERNATIONAL JOURNAL OF ACADEMIC RESEARCH IN BUSINESS AND SOCIAL SCIENCES Vol. 10, No. 8, 2020, E-ISSN: 2222-6990 @ 2020 HRMARS

1 - Physiological causes: These are organic causes caused by a brain injury or injury to one of the speech organs of a particular disorder. Therefore language disorders occur as a result of injury to the brain organs or cerebral cortex, or as a result of injury to the throat, nose, throat, lungs, or ear with infections, or as a result of deformation of dental regularity, or damage to nerve cells in addition to severe physical weakness, weak senses and mental weakness or as a result of injury sore throat, lip, asymmetry of the jaws, insufficient glands, or as a result of diseases that affect the chest and lungs.

2 - Psychological and Social Causes: There are psychological factors that a child may be exposed to, which negatively affects language disorders, as anxiety resulting from fear, tension, conflict, emotional shocks, nervousness, convergence, aggression and poor self-confidence are among the most important reasons leading to speech and word disorder. The child's feeling of neglect, deficiency, emotional deprivation, failure to satisfy the psychological and emotional wants and needs, and lack of knowledge of identifying right from wrong, which leads to the child being affected negatively from a psychological point of view. The separation of parents from each other leads to a lack of psychological care for the child. One of the reasons affecting the child's psyche is also the multiplicity of languages or dialects that the child hears at the time the child acquires language. The cultural level also affects the child's psyche at the cultural level. An educated family assists its child in acquiring a sound and error-free language, while a non-educated family can only acquire a child with a culture at the level of its culture.

\section{Literature Review}

Azzam (2006) conducted a study that aimed to reveal the extent and nature of the relationship between language disorders and children learning difficulties. The study attempts to identify the extent to which both males and females were affected by linguistic strikes and their relationship to learning difficulties. The sample was equally selected from the age of (6-12 years) between males and females from children with learning difficulties. The researcher used more than one tool, including the fourth edition Binet Arab Scale and the questionnaire for parents and the school. The most prominent results were the presence of a significant relationship between language disorders and learning difficulties, as it was found that $53 \%$ of the male sample suffered delaying speech, first-word pronunciation and pronouncing simple sentences in their early stages of development. In the female sample, $46 \%$ found delays in eloquence, first-word pronunciation and pronouncing a simple sentence. The results also showed that the relationship between language disorders and learning difficulties was clear and more influential for the male sample.

Jalghoum (2007) also conducted a study that aimed at showing the effect of a treatment program used in reducing language disorders, as the current study sample was limited to one student (case study). The student was chosen at the beginning of the 2006/2007 academic year and he is a student in the second basic class in the kindergarten and School of National Knowledge College, where several tools were used, including observation, notification, the Wexler Scale for Measuring Children's Intelligence and the Diagnostic Scale for Basic Skills in the Arabic Language (Cognitive-Visual Tests, Auditory Cognitive Tests and the Therapeutic Program). The results showed that the therapeutic educational program had a significant impact on the improvement at the academic and emotional level of the student due to the consideration of integrated program basic language skills. 
INTERNATIONAL JOURNAL OF ACADEMIC RESEARCH IN BUSINESS AND SOCIAL SCIENCES Vol. 10, No. 8, 2020, E-ISSN: 2222-6990 (C) 2020 HRMARS

Urlike and Julth (2003) conducted a study on 94 children through which they compared ordinary children and children with learning difficulties in terms of linguistic problems and behavioural problems. The results showed that the expressive language difficulties for people with learning difficulties were represented by little speaking, the presence of a few linguistic outcomes, poor awareness of vocabulary meanings, the abbreviation of sentences, and poor use of grammar, while the difficulties of receptive language were poor understanding and poor understanding of simple and complex words and phrases.

\section{Results}

To answer the first question, which reads: What are the language disorders among basic level students from female teachers' viewpoint in government schools in the Wasatiya District of Irbid governorate?

To answer this question, arithmetic mean and standard deviations were calculated for study sample vocabulary concepts at the level of each paragraph and total variable for linguistic disorders.

Table (1) shows the results of arithmetic averages and standard deviations for language disorders variable for study sample vocabulary concepts.

\begin{tabular}{|c|c|c|c|c|c|}
\hline the level & $\begin{array}{l}\text { standard } \\
\text { deviation }\end{array}$ & SMA & Paragraph & $\begin{array}{l}\text { Ran } \\
\mathbf{k}\end{array}$ & $\begin{array}{l}\text { Paragrap } \\
\text { h } \\
\text { number }\end{array}$ \\
\hline Average & 1.11 & 3.04 & $\begin{array}{l}\text { He suffers from a decrease in his linguistic } \\
\text { outcome compared to his classmates }\end{array}$ & 14 & 1. \\
\hline Average & 1.03 & 3.07 & $\begin{array}{l}\text { Avoid speaking in class due to the inability } \\
\text { to properly spell letters and words }\end{array}$ & 22 & 2. \\
\hline Average & 1.04 & 3.10 & $\begin{array}{l}\text { He does not volunteer to answer oral } \\
\text { questions as a result of his language } \\
\text { disorder (stuttering, substitution, } \\
\text { distortion. deletion) }\end{array}$ & 10 & 3. \\
\hline Average & 1.02 & 3.05 & $\begin{array}{l}\text { Others do not understand it clearly due to } \\
\text { linguistic errors in letter output }\end{array}$ & 21 & 4. \\
\hline Average & 1.04 & 3.17 & $\begin{array}{l}\text { It needs to repeat the oral answer to correct } \\
\text { linguistic errors }\end{array}$ & 3 & 5. \\
\hline Average & 1.08 & 2.98 & $\begin{array}{l}\text { He stops or hesitates while speaking for fear } \\
\text { of his linguistic mistakes }\end{array}$ & 20 & 6. \\
\hline
\end{tabular}


INTERNATIONAL JOURNAL OF ACADEMIC RESEARCH IN BUSINESS AND SOCIAL SCIENCES Vol. 10, No. 8, 2020, E-ISSN: 2222-6990 @ 2020 HRMARS

\begin{tabular}{|c|c|c|c|c|c|}
\hline the level & $\begin{array}{l}\text { standard } \\
\text { deviation }\end{array}$ & SMA & Paragraph & $\begin{array}{l}\text { Ran } \\
\mathbf{k}\end{array}$ & $\begin{array}{l}\text { Paragrap } \\
\text { h } \\
\text { number }\end{array}$ \\
\hline \multirow[t]{2}{*}{ Average } & & & Repeats sounds or words when speaking & & 7. \\
\hline & 1.09 & 3.10 & & 6 & \\
\hline \multirow[t]{2}{*}{ Average } & & & Unable to spell words correctly & & 8. \\
\hline & 1.04 & 2.93 & & 23 & \\
\hline \multirow[t]{2}{*}{ Average } & & & It goes on in the sounds of some words & & 9. \\
\hline & 1.06 & 3.06 & & 15 & \\
\hline \multirow[t]{2}{*}{ Average } & & & More than one word is used in the same & & 10. \\
\hline & .99 & 3.16 & & 19 & \\
\hline \multirow[t]{2}{*}{ Average } & & & Stuttering affects the preparation of the & & 11. \\
\hline & 1.24 & 3.36 & $\begin{array}{l}\text { appropriate answer to the question posed } \\
\text { to it }\end{array}$ & 1 & \\
\hline \multirow[t]{2}{*}{ Average } & & & Uses weak and sub-vocabulary & & 12. \\
\hline & 1.07 & 3.22 & & 2 & \\
\hline \multirow[t]{2}{*}{ Average } & & & He uses simple names and some inaccurate & & 13. \\
\hline & 1.11 & 3.14 & descriptive words to express what he says & 7 & \\
\hline \multirow[t]{2}{*}{ Average } & & & It uses missing sentences that full of & & 14. \\
\hline & 1.00 & 3.14 & grammatical errors & 5 & \\
\hline \multirow[t]{2}{*}{ Average } & & & It uses incomplete sentences & & 15. \\
\hline & 1.02 & 3.20 & & 4 & \\
\hline \multirow[t]{2}{*}{ Average } & & & Unable to remember the words required for & & 16. \\
\hline & 1.17 & 3.08 & the answer during the lesson & 11 & \\
\hline \multirow[t]{2}{*}{ Average } & & & He often strives to find the right words to & & 17. \\
\hline & 1.12 & 3.10 & express himself & 9 & \\
\hline
\end{tabular}


INTERNATIONAL JOURNAL OF ACADEMIC RESEARCH IN BUSINESS AND SOCIAL SCIENCES Vol. 10, No. 8, 2020, E-ISSN: 2222-6990 @ 2020 HRMARS

\begin{tabular}{|c|c|c|c|c|c|}
\hline the level & $\begin{array}{l}\text { standard } \\
\text { deviation }\end{array}$ & SMA & Paragraph & $\begin{array}{l}\text { Ran } \\
\mathbf{k}\end{array}$ & $\begin{array}{l}\text { Paragrap } \\
\text { h } \\
\text { number }\end{array}$ \\
\hline Average & 1.06 & 3.03 & $\begin{array}{l}\text { Unable to tell a full and understandable } \\
\text { story }\end{array}$ & 13 & 18. \\
\hline Average & 1.03 & 3.00 & $\begin{array}{l}\text { He has difficulty in sequentially and logically } \\
\text { organizing and describing ideas }\end{array}$ & 16 & 19. \\
\hline Average & 1.10 & 2.75 & $\begin{array}{l}\text { Unable to relate his ideas and produce } \\
\text { expressive ideas }\end{array}$ & 25 & 20. \\
\hline Average & 1.05 & 2.92 & $\begin{array}{l}\text { Unable to focus to ensure continuity and } \\
\text { communication to speak ideas }\end{array}$ & 24 & 21. \\
\hline Average & 1.00 & 3.09 & Unable to follow the class discussion & 18 & 22. \\
\hline Average & 1.08 & 3.07 & $\begin{array}{l}\text { It takes a long time to organize his thoughts } \\
\text { before he responds }\end{array}$ & 17 & 23. \\
\hline Average & 1.02 & 3.11 & Unable to remember the printed word & 12 & 24. \\
\hline Average & 1.17 & 3.20 & He has impaired audiovisual memory & 8 & 25. \\
\hline Average & .75 & 3.09 & Total & & \\
\hline
\end{tabular}

It appears from Table No. (1) that the general mean of study sample vocabulary concepts for the variable of language disorders came with an average degree, with an average score of (3.09) and a standard deviation (0.75). Paragraph No. (11) "stuttering affects the preparation of the appropriate answer to the question posed to it." Ranked first with an average mathematical average of (3.36) and with a degree of medium approval, while Paragraph No. (20) "unable to link his thoughts and produce ideas expressing his idea" in the last rank among the variable paragraphs reflects with an arithmetic average of (2.75) and an average degree of approval.

To answer the second question from which the main hypothesis emerged, which states: There are no statistically significant differences at the level of significance $(\alpha \leq 0.05)$ in the linguistic disorder of 
INTERNATIONAL JOURNAL OF ACADEMIC RESEARCH IN BUSINESS AND SOCIAL SCIENCES

Vol. 10, No. 8, 2020, E-ISSN: 2222-6990 @ 2020 HRMARS

basic levels from female teachers' point of view due to demographic variables (age, educational qualification, years of experience and grade of study?

To answer this hypothesis, Multiple Anova was used. Table (5) shows the results of multiple variance analysis to reveal the differences in sample's estimates for the level of language disorders that is attributable to variables (age, educational qualification, years of experience, and grade of study).

\begin{tabular}{|c|c|c|c|c|c|}
\hline $\begin{array}{l}\text { Significa } \\
\text { nce level }\end{array}$ & $\begin{array}{l}\text { Value } \\
\text { (q) }\end{array}$ & $\begin{array}{l}\text { Average } \\
\text { squares }\end{array}$ & $\begin{array}{l}\text { Degrees } \\
\text { of } \\
\text { freedom }\end{array}$ & $\begin{array}{l}\text { Sum } \\
\text { squares }\end{array}$ & Source of contrast \\
\hline .353 & 1.098 & .548 & 3 & 1.643 & Age \\
\hline .191 & 1.611 & .803 & 3 & 2.409 & Qualification \\
\hline $.001 *$ & 7.481 & 3.730 & 2 & 7.460 & Years of Experience \\
\hline \multirow[t]{3}{*}{.462} & .865 & .431 & 3 & 1.294 & $\begin{array}{l}\text { The class of } \\
\text { studying }\end{array}$ \\
\hline & & .499 & 118 & 58.837 & The error \\
\hline & & & 130 & 1321.245 & Total \\
\hline
\end{tabular}

* Statistically significant at the level $(0.05 \geq \alpha)$

The data in Table 5 indicates that there are no statistically significant differences at the level of significance $(\alpha \leq 0.05)$ in the estimates of study sample vocabulary for linguistic disorders attributed to the variables (age, educational qualification and grade of study), while data indicate the presence of statistically significant differences at the level of significance $(\alpha \leq 0.05)$ in the estimates of study sample vocabulary for language disorders attributed to a variable (years of experience).

\section{Discussion of the Results}

Discussing the results of the first question, where the most prominent disorders facing basic level students were from basic level female teachers' point of view are as follows: 1 - stuttering affects the preparation of appropriate answer to the question posed to it 2 - uses weak vocabulary and below his age level 3 - repeats the oral answer to correct his language errors 4- Frequently uses incomplete sentences 5- uses missing sentences full of grammatical errors.

The researcher attributes this to factors that may be psychological, social, or nervous, as education and socialization may have a major role in the occurrence of such disorders. The education methods based on corporal punishment, reprimand and insult often lead an individual to experience psychological effects and frustrations that hinder the educational process among students and influence the level of academic achievement. Parents' neglect of their children and their attempt to 
insult their children in front of strangers or silence them when speaking in front of others leads to discovering psychological and negative sediments that destabilize self-confidence and makes the child doubt his ability to speak correctly, whether in school or front of others. This leads to stuttering in speech, grammatical errors, and repetition of some words or sentences. Also, these disorders may be the result of damage to the nervous system during or after birth.

This study also coincides with the study of Eurylich \& Gelth, (2003), the results of their study were that the difficulties of an expressive language for people with learning difficulties are speaking a little, presence of a few linguistic outcomes, poor awareness of vocabulary meanings and poor use of grammar, while difficulties in the receptive language were poor understanding and poor understanding of simple and complex words and phrases.

\section{Discussion of main hypothesis results}

Where its result includes

1- Acceptance of the hypotheses with its three demographic variables (age, educational qualification, the grade of studying) as there are no statistically significant differences at the level of significance $(\alpha \leq 0.05)$ and the researcher interprets this to the fact that these variables are not useful in discovering difficulties in learning about language disorders, as it needs a special study by a specialist to identify and discover it and that is by a psychologist, neurologist or linguist, and this is what was agreed by Al-Dabbas (2012).

2- The hypothesis was rejected by variable (years of experience), where the data indicated that there were statistically significant differences at the level of significance $(\alpha \leq 0.05)$ in estimating study sample vocabulary for language disorders, and the researcher explains that teacher's educational experience is important in the education process where the teacher can recognize more students with learning difficulties in general and the difficulties of writing and language disorders in particular because educational experience improves the ability to recognize and discover the symptoms of these disorders even if it is simple indications that help in reducing and treating them early and quickly.

\section{Conclusion}

Linguistic disorders emerge as a result of the inability to appropriately use language in communication skills. The paper has examined a range of issues causing linguistic disorders among Irbid basic stage students and discovered that many factors including the weak uses of vocabulary, repetition of language errors, often uses of incomplete sentences and inappropriate uses of sentence share in the problem. Factors like social, psychological and nervous disorders were also linked by the researchers to the existence of linguistic disorders in children.

While students with linguistic disorders possess sluggish language development from childhood to adulthood, students with moderate language impairment have phonological and speech sound acquisition difficulties. In this regard, early and effective intervention are highly required from medical and educational experts. Setting appropriate treatment plans and programs by allocating classes for their treatment are other ways of overcoming the challenges of the linguistic disorder. As a matter of importance, the challenges also give room for including specialists and psychology counsellors in every school. 
INTERNATIONAL JOURNAL OF ACADEMIC RESEARCH IN BUSINESS AND SOCIAL SCIENCES Vol. 10, No. 8, 2020, E-ISSN: 2222-6990 @ 2020 HRMARS

\section{References}

Ahmad, J. A. D. A. (2007). Early detection of the prevalence of learning difficulties for those with poor academic achievement in primary schools and their relationship to some variables.

Al-Baddour, T. M. (2013). The Effectiveness of a Training Program Based on Neuro-Linguistic Stuttering Theory among a Sample of Jordanian Children. University of Islamic Sciences. Unpublished doctoral thesis.

Al-Dabbas, S. Y. (2013). Language disorders and their treatment. Al-Quds Open University Journal for Research and Studies. Vol (29). Issue (2).

Al-haashimi, I., \& Arar, S. (2016). Language and communication disorders, diagnosis and treatment. Journal of Humanities and Social Sciences. Issue (24).

American Psychiatric Association. (2013). Diagnostic and statistical manual of mental disorders (5th ed.). Washington, DC: American Psychiatric Association.

An-nuubi, M. A. (2011). Learning difficulties between skills and disorders. Al-Safa House for Publishing and Distribution, $1^{\text {st }}$ edition.

Azzam, S. (2006). Language disorders and their relationship to child learning difficulties. College of Education, Saudi Arabia.

Celia, H., \& Houria, H. (2017). Linguistic disorders and their effect on reading skill for first year students in primary education. Master Thesis, Abdul Rahman Mira University, College of Arts and Languages.

Didouh, O. (2016). Language disorders and child communication issue. Master Degree, Bakr Belkaid University.

El-Faramawy, H. A. (2009). Speech disorders (speech - speech - language - sound). Amman, Dar AlSafa for Publishing and Distribution, $1^{\text {st }}$ edition.

Fayoumi, K. (2017). Word and speech disorders among Jordan primary stage students in light of their relationship with some variables. The Jordanian Journal of Educational Sciences. Issue (2).

Hallahan, D. P., Kauffman, J. M., \& Pullen, P. C. (2012). Exceptional learners, an introduction to special education. Pearson Education, Inc, MA, Allyn \& Bacon, Boston. 12 ED.

Jalghoum, S. A. (2007). The effect of a therapeutic program in reducing language disorders in a second-grade primary student (case study). Arabic Open University.

Mahmoud, O. (2007). Some personal and social skills difficulties for children with learning difficulties. Master Thesis, Beirut Arab University.

Newborg, J. (2005). Battelle Developmental Inventory, Second Edition. Itasca, IL Riverside Publishing.

Paul, R., \& Norbury, C. (2012). Language disorders from infancy through adolescence: Listening, speaking, reading, writing, and communicating. St. Louis, Mo: Mosby.

Tomblin, J. B., Records, N. L., Buckwalter, P., Zhang, X., Smith, E., \& O’Brien, M. (1997). Prevalence of specific language impairment in kindergarten children. Journal of Speech, Language, and Hearing Research, 40(6), 1245-1260.

Ulrike, E., \& Julth, G. B. (2003). Behavior in children with language impairment. Journal of Psychiatry, 48, 607-614.

Ulu, F. (2015). Language disorders and child communication issue. Master Thesis, University of Abi Bakr Belkaid. 
INTERNATIONAL JOURNAL OF ACADEMIC RESEARCH IN BUSINESS AND SOCIAL SCIENCES Vol. 10, No. 8, 2020, E-ISSN: 2222-6990 @ 2020 HRMARS

Woods, P. L., Rieger, I., Wocadlo, C., \& Gordon, A. (2014). Predicting the outcome of specific language impairment at five years of age through early developmental assessment in preterm infants. Early Human Development, 90(10), 613-619. doi: 10.1016/j.earlhumdev.2014.07.010

World Health Organization. (2010). Framework for Action on Interprofessional Education \& Collaborative Practice. Geneva: WHO Press. 